\title{
Gentiana asclepiadea and Armoracia rusticana can modulate the adaptive response induced by zeocin in human lymphocytes
}

\author{
A. HUDECOVA ${ }^{* 1}$, K. HASPLOVA ${ }^{1}$, L. KELLOVSKA ${ }^{1}$, M. IKRENIOVA ${ }^{1}$, E. MIADOKOVA ${ }^{1}$, E. GALOVA ${ }^{1}$, E. HORVATHOVA ${ }^{2}$, D. VACULCIKOVA ${ }^{3}$, \\ F. GREGAN ${ }^{3}$, M. DUSINSKA ${ }^{4}$
}

${ }^{1}$ Department of Genetics, Faculty of Natural Sciences, Comenius University, Mlynská dolina, 842 15, Bratislava, Slovakia; ${ }^{2}$ Laboratory of Mutagenesis and Carcinogenesis, Cancer Research Institute, Slovak Academy of Sciences, Vlárska 7, 833 91, Bratislava, Slovakia; ${ }^{3}$ Department of Chemistry, Faculty of Natural Sciences, Matej Bel University, Banská Bystrica, Slovakia; ${ }^{4}$ Centre for Ecology and Economics (CEE), Health Effects Laboratory, Norwegian Institute for Air Research, Instituttveien 18, 2027 Kjeller, Norway

${ }^{*}$ Correspondence: hudecovaa@fns.uniba.sk

Received July 11, 2011 / Accepted August 15, 2011

\begin{abstract}
Zeocin is a member of bleomycin/phleomycin family of antibiotics isolated from Streptomyces verticullus. This unique radiomimetic antibiotic is known to bind to DNA and induce oxidative stress in different organisms producing predominantly single- and double- strand breaks, as well as a DNA base loss resulting in apurinic/apyrimidinic (AP) sites. The aim of this study was to induce an adaptive response (AR) by zeocin in freshly isolated human lymphocytes from blood and to observe whether plant extracts could modulate this response. The AR was evaluated by the comet assay. The optimal conditions for the AR induction and modulation were determined as: 2 h-intertreatment time (in PBS, at $\left.4^{\circ} \mathrm{C}\right)$ given after a priming dose $(50 \mu \mathrm{g} / \mathrm{ml})$ of zeocin treatment. Genotoxic impact of zeocin to lymphocytes was modulated by plant extracts isolated from Gentiana asclepiadea (methanolic and aqueous haulm extracts, $0.25 \mathrm{mg} / \mathrm{ml}$ ) and Armoracia rusticana (methanolic root extract, $0.025 \mathrm{mg} / \mathrm{ml}$ ). These extracts enhanced the AR and also decreased DNA damage caused by zeocin (after 0,1 and $4 \mathrm{~h}$-recovery time after the test dose of zeocin application) to more than $50 \%$. These results support important position of plants containing many biologically active compounds in the field of pharmacology and medicine.
\end{abstract}

Key words: adaptive response, zeocin, Gentiana asclepiadea, Armoracia rusticana, genotoxicity

An adaptive response as a nonspecific phenomenon has been observed during last 20 years with many organisms starting with bacteria up to mammalian organisms including humans. Cells, tissues and organisms can often improve their ability to respond to a "challenging" stress when they have been exposed previously to a smaller, „inducing“ amount of the same or a similar stress [1-2]. Many different types of damaging agents, including radiation, heat stress, oxidative stress, alkylating agents, and heavy metals have been reported to induce an adaptive response. Such protective response also indicates that the cell, once exposed to the toxin, expects, or at least is prepared for, a subsequent lethal dose [3].

In recent years the use of antibiotics in chemotherapy has become more extensive. Zeocin is a member of bleomycin/ phleomycin family of antibiotics isolated from culture broth of a Streptomyces verticullus mutant. It can bind to DNA and induce oxidative stress in different organisms producing pre- dominantly single- (SSBs) and double- strand breaks (DSBs), as well as a DNA base loss resulting in apurinic/apyrimidinic (AP) sites [1,4-5].

The use of plants and herbs for medicinal purposes is as old as mankind. Of all medicines, $30-40 \%$ today contains one or more active components derived from plants. Recently much attention has been given to the natural phytochemicals with antioxidant, antimutagenic and anticarcinogenic activities [6-11]. These compounds are of a great importance for chemoprevention and potential cancer biotherapy [12].

Gentiana asclepiadea belongs to the Gentianaceae family. These plants are widely used in traditional medicine in many countries for stimulation of appetite and gastric secretion, gastro-duodenal protection, liver protection, antifungal treatment, and in some cases for gynaecological diseases [13]. Experimental studies have showed, that Gentiana contains as main components compounds such as secoiridoid-glycosides 
(gentiopicroside, sweroside, swertiamarin, amarogentin), xanthone glycosides (gentioside and its isomer), terpenes, xanthones (gentisin, isogentisin), secoiridoids (gentiopicrine), alkaloids (gentianine, gentiabetin, gentianidine, gentialutin), anthocyanins (delphinidine) and flavone C-glucosides [1420]. Iridoids are the most common constituents of genus Gentiana, and they have been found to exhibit a wide range of bioactivities including antibacterial, anticancer, antifungal, antioxidant, anti-inflammatory, anticoagulant, choleretic, cardioprotective, hepatoprotective, neuroprotective, hypoglycaemic, antispasmodic, immunomodulatory and purgative properties [16,21-22].

Armoracia rusticana (horseradish) is a perennial crop belonging to the genus Armoracia of the Brassicaceae family. Its roots are popularly used as a pungent spice and an indispensable material for producing horseradish paste and pungent sauces. Horseradish root contains horseradish peroxidase, approx. $0.6 \%$ of glucosinolates and the most abundant of these are sinigrin $(0.2 \%)$ and gluconasturtiin $(0.1 \%)$. As soon as intact cells are damaged, these isothiocyanates are enzymatically hydrolyzed to yield allyl isothiocyanate and 2-phenylethyl isothiocyanate, respectively. Further glucosinolates in horseradish are glucobrassicanapin and the indol-derived glucobrassicin (plus some closely related compounds like 4-methoxy glucobrassicin, 4-hydroxy glucobrassicin). Among the non-volatile constituents, one should mention flavone glycosides (quercetine, kaempferol) and particularly ascorbic acid, which is contained to $0.6 \%$ in horseradish root [23-25].

The aim of this study was to induce an adaptive response by zeocin in human lymphocytes and to observe whether G. asclepiadea haulm methanolic and aqueous and A. rusticana methanolic root extracts could modulate this response using the comet assay and the constant field gel electrophoresis.

\section{Materials and methods}

Plant material. Gentiana asclepiadea and Armoracia rusticana plants were harvested from the Garden of Medicinal Plants, Faculty of Pharmacy, Comenius University. The air dried separated plant material was cut into small pieces and then extracted with methanol or water at $65^{\circ} \mathrm{C}$. This procedure was repeated 5 times. The hot solution of the extract was then filtered and concentrated by distillation by the vacuum rotatory evaporator. The rest of the water was removed by azeotropic distillation with benzene. The final extracts (G. asclepiadea haulm methanolic - GAM and aqueous - GAA; A. rusticana root methanolic - ARM) were kept in the dark at $4^{\circ} \mathrm{C}$ until tested.

Lymphocytes. Human lymphocytes were obtained by the finger prick method just before use [according to 26]. $30 \mu \mathrm{l}$ of blood were taken and added to $1 \mathrm{ml}$ of PBS buffer ( $\mathrm{pH} 7.5$ ), mixed and left on ice up to $30 \mathrm{~min}$. Afterwards, blood was underlayed with $100 \mu \mathrm{l}$ Histopaque 1077 (Sigma), spinned at $180 \times \mathrm{g}$ for $5 \mathrm{~min}$ at $4^{\circ} \mathrm{C}$. Lymphocytes $(100 \mu \mathrm{l})$ were retrieved from just above the boundary between PBS buffer and Histopaque and spinned again in new eppi tubes containing $1 \mathrm{ml}$ of PBS at $180 \times \mathrm{g}, 5 \mathrm{~min}, 4^{\circ} \mathrm{C}$. Supernatant was removed and lymphocytes were used as needed.

RPMI medium. RPMI-1640 medium (RPMI) purchased from Sigma Aldrich (supplemented with $10 \%$ fetal calf serum and $100 \mathrm{U} / \mathrm{ml}$ penicillin and $100 \mu \mathrm{g} / \mathrm{ml}$ streptomycin) was used for intertreatment and recovery after treatment with priming and test doses of zeocin during adaptive response experiments.

Zeocin. Zeocin was purchased from Invitrogen. It was prepared freshly before use by dilution in PBS buffer ( $\mathrm{pH}$ 7.5) and kept and handled in the dark.

Treatment, pretreatment and design for adaptive response and recovery experiments. All treatments for the comet assay were performed on isolated lymphocytes on microscopic slides covered by parafilm.

Application of zeocin on human lymphocytes for determination of its potential genotoxic effect. Freshly prepared zeocin was diluted in PBS and applied for 1 or $10 \mathrm{~min}$, in the dark on ice. After the treatment, slides were washed in PBS buffer and submitted to the comet assay.

Treatment with the plant extracts. Plant extracts diluted in PBS were applied on the slides with isolated lymphocytes and left for $30 \mathrm{~min}$ in $37^{\circ} \mathrm{C}$. After the treatment, slides were washed in PBS buffer.

Design for adaptive response and recovery experiments with zeocin in RPMI or PBS at 37 or $4^{\circ} \mathrm{C}$. Freshly prepared zeocin (priming dose: $50 \mu \mathrm{g} / \mathrm{ml}$ in PBS) was applied on the prepared slides for $1 \mathrm{~min}$ in the dark on ice. After the treatment with priming dose, slides were washed in PBS buffer and left in RPMI at $37^{\circ} \mathrm{C}$, PBS at $37^{\circ} \mathrm{C}$, RPMI at $4{ }^{\circ} \mathrm{C}$ and PBS at $4^{\circ} \mathrm{C}$ for $0,1,2$ and $4 \mathrm{~h}$-intertreatment time before treatment with the test dose of zeocin $(300 \mu \mathrm{g} / \mathrm{ml}$ in PBS). After that, slides were washed in PBS buffer, left in conditions RPMI at $37^{\circ} \mathrm{C}$, PBS at $37^{\circ} \mathrm{C}$, RPMI at $4{ }^{\circ} \mathrm{C}$ and PBS at $4^{\circ} \mathrm{C}$ for $0,1,2$ and $4 \mathrm{~h}$ recovery time and submitted to the comet assay.

Design for adaptive response and recovery experiments with zeocin and plant extracts in PBS at $4^{\circ} \mathrm{C}$. Freshly prepared zeocin (priming dose: $50 \mu \mathrm{g} / \mathrm{ml}$ in PBS) was applied on the prepared slides for $1 \mathrm{~min}$ in the dark on ice. After the treatment with priming dose, slides were washed in PBS buffer and plant extracts were applied for $30 \mathrm{~min}$. Slides were then washed in PBS and left for $2 \mathrm{~h}$-intertreatment time in PBS at $4^{\circ} \mathrm{C}$ before treatment with the test dose of zeocin $(300 \mu \mathrm{g} / \mathrm{ml})$. After that, slides were washed in PBS buffer, left in PBS for 0, 1 and 4 h-recovery time and submitted to the comet assay.

The constant field gel electrophoresis (CFGE). The CFGE method is based on incorporation of cells into agarose blocks before cell lysis. This method detects DSBs and is sensitive with high resolution and can be applied in chemical mutagenesis $[4,27]$. We followed this manual: Isolation of human lymphocytes was the same as we described in paragraph 2.2, with modification $-100 \mu \mathrm{l}$ of blood was taken and after first centrifugation $300 \mu$ l of lymphocytes were retrieved. Cells were 
incubated in eppi tubes for $30 \mathrm{~min}$ at $37^{\circ} \mathrm{C}$ with plant extracts in given concentrations: Gentiana asclepiadea: $0.25 \mathrm{mg} / \mathrm{ml}$ (haulm aqueous and methanolic extract), Armoratia rusticana: $0.025 \mathrm{mg} / \mathrm{ml}$ methanolic root extract (3 eppi tubes), the positive controls (another 3 eppi tubes) were treated with $\mathrm{H}_{2} \mathrm{O}_{2}(300 \mu \mathrm{M}$ ) for $5 \mathrm{~min}$ (on ice), zeocin $50 \mu \mathrm{g} / \mathrm{ml}$ and 300 $\mu \mathrm{g} / \mathrm{ml}$. The last eppi tube was a negative control without any treatment. Subsequently cells were spinned at $180 \times \mathrm{g}$ for 5 min at $4^{\circ} \mathrm{C}$. The cells (approx. $3 \times 10^{4}$ per agarose blocks) were resuspended in $0.8 \%$ low melting point (LMP) agarose in 0.5 $\mathrm{x}$ TBE (stock solution $10 \times$ TBE: $0.9 \mathrm{M}$ TRIS, $0.9 \mathrm{M}$ boric acid, $0.02 \mathrm{M}$ EDTA, $\mathrm{pH}$ 8.3) and were put into the blocks for solidifying (30 min on ice). All agarose blocks were placed in lysis solution $(2.5 \mathrm{M} \mathrm{NaCl}, 100 \mathrm{mM} \mathrm{Na}$ EDTA, $10 \mathrm{mM}$ Tris-HCl, $\mathrm{pH} 10$ and $1 \%$ Triton X-100, $\mathrm{pH} 10$ ) at $4^{\circ} \mathrm{C}$ for $1 \mathrm{~h}$. After that blocks were neutralized in PBS two times and were inserted into the holes on gel $(2.4 \mathrm{~g}$ AGAR ST IMUNA, $1 \times \mathrm{TBE}, 0.5$ $\mu \mathrm{g} / \mathrm{ml} \mathrm{EtBr}$ ). As an electrophoresis solution $0.5 \times \mathrm{TBE}$ was used and the electrophoresis run under following conditions: $20 \mathrm{~V}, 10 \mathrm{~mA}$ (constant field), $40 \mathrm{~h}$. Gel was visualized by Gel Capture Version 4.24 with transimulator DNR Bio Imaging Systems Ltd.

The comet assay. The comet assay was performed following the protocol of Collins et al. [26]. Briefly: microscope slides were pre-coated with base layer of $100 \mu \mathrm{l}$ of $1 \%$ normal melting point (NMP) agarose in water. The cells (approx. $1 \times 10^{4}$ per gel) were resuspended in $1 \%$ low melting point (LMP) agarose in PBS buffer (pH 7.5) and spread on pre-coated slides. Two gels per slide were prepared. All slides were placed in lysis solution (2.5 M NaCl, $100 \mathrm{mM} \mathrm{Na}$ EDTA, $10 \mathrm{mMl}$ Tris- $\mathrm{HCl}$, pH 10 and $1 \%$ Triton $\mathrm{X}-100, \mathrm{pH} 10$ ) at $4^{\circ} \mathrm{C}$ for $1 \mathrm{~h}$ to remove cellular membrane and cytoplasm, leaving nuclei. After lysis, the slides were transferred to an electrophoretic tank containing alkaline solution ( $300 \mathrm{mM} \mathrm{NaOH}, 1 \mathrm{mM} \mathrm{Na}$ EDTA, $\mathrm{pH} 13)$ for $20 \mathrm{~min}$ at $4{ }^{\circ} \mathrm{C}$ to allow the DNA to unwind. The electrophoresis run under following conditions: $25 \mathrm{~V}, 300 \mathrm{~mA}, 30 \mathrm{~min}$. The slides were removed and neutralized in $\mathrm{PBS}(10 \mathrm{~min})$ and $\mathrm{ddH}_{2} \mathrm{O}(10$ $\mathrm{min})$ at $4^{\circ} \mathrm{C}$. Each sample was stained with $25 \mu \mathrm{l} \mathrm{EtBr}(1 \%$ stock

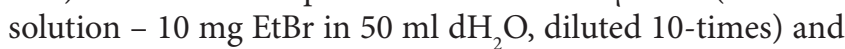
per each sample 100 nucleoids per each sample were scored by visual scoring for determination of DNA strand breaks.

\section{Results}

In order to test whether zeocin possesses DNA damaging (genotoxic) potential in human lymphocytes we used a scale of eleven concentrations in the range from 50 to $600 \mu \mathrm{g} / \mathrm{ml}$ with the treatment time of 1 and 10 minutes using the comet assay (Fig. 1). It was found that the genotoxic effect of zeocin in the range of $50-300 \mu \mathrm{g} / \mathrm{ml}$ concentrations could be considered as linearly increasing with the concentration (Fig. 1). In the range of $300-600 \mu \mathrm{g} / \mathrm{ml}$ the levels of induced DNA damage was approximately constant and reached the maximum detectable damage by the comet assay and the curve flattened out to a plateau. For further experiments with the adaptive response, two concentrations were chosen: $50 \mu \mathrm{g} / \mathrm{ml}$ as a priming (conditioning) dose and $300 \mu \mathrm{g} / \mathrm{ml}$ as a test (challenge) dose.

CFGE method (Fig. 2) was used to detect DNA DSBs in zeocin or plant extracts. Interestingly, we found that both concentrations of zeocin (50 and $300 \mu \mathrm{g} / \mathrm{ml}$ ) induce DSBs. On the contrary, no signs of DSBs were observed after the treatment of lymphocytes with plant extracts.

We have compared the potential adaptive response induction by zeocin in freshly isolated lymphocytes according to

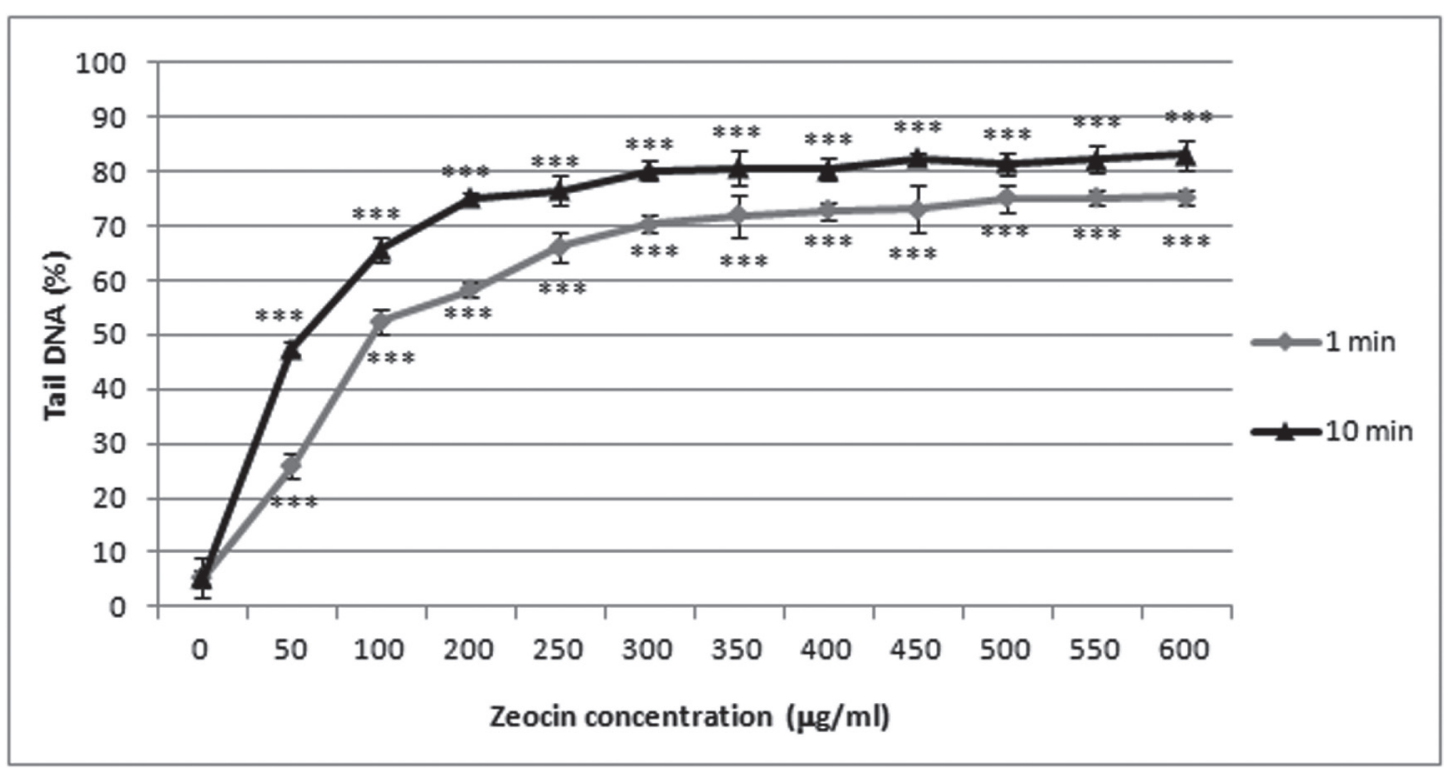

Figure 1. Genotoxic activity of zeocin studied in human lymphocytes. Different concentrations of zeocin $(50-600 \mu \mathrm{g} / \mathrm{ml})$ and time of treatment $(1 \mathrm{or}$ 10 minutes) were studied using the comet assay. All experiments were performed at least four times. Mean values \pm SD. ${ }^{* *} P<0.001$ 
experimental conditions: intertreatment in PBS buffer for different time after the priming dose $(0,1,2$ and $4 \mathrm{~h})$ and recovery after the test dose $(0,1,2$ and $4 \mathrm{~h})$ at $4^{\circ} \mathrm{C}$ (Fig. 3$)$. The best results were observed after $2 \mathrm{~h}$-intertreatment time.

The next question we addressed was whether plant extracts (G. asclepiadea methanolic and aqueous $-0.25 \mathrm{mg} / \mathrm{ml}$ and $A$. rusticana methanolic extract $-0.025 \mathrm{mg} / \mathrm{ml}$ ) could modulate the adaptive response induced by zeocin in human lymphocytes. Results obtained after $2 \mathrm{~h}$-intertreatment time after the priming dose of zeocin and its modulation with the plant extracts (30 min) showed (Fig. 4) that extracts enhanced the AR induced by zeocin and reduced its effect to more than $50 \%$ (from approx. $42 \%$ DNA damage to 19\% GAM, 16,75\% GAA and $16,75 \%$ ARM). It also enhanced DNA repair after 1 and 4 h-recovery time.

\section{Discussion}

A lot of data are available concerning the use of zeocin as a selective agent for isolation of transformants in various testsystems $[5,28]$ but data concerning DNA-damaging potential and zeocin molecular mechanism of action are scarce. Zeocin belongs to the bleomycin/phleomycin family of antibiotics which have radiomimetic properties (InvivoGEN, http://www. invivogen.com). It is known that bleomycin induces oxidative DNA damage and DNA cleavage in mammalian cells [29]. Our results, measured by the comet assay, showed that zeocin similarly to bleomycin causes DNA damage in freshly isolated human lymphocytes (Fig. 1). A dose-dependent increasing of zeocin-induced DNA damage was found up to $300 \mu \mathrm{g} / \mathrm{ml}$. It could be said that this concentration of zeocin marked the beginning of a plateau because there was no statistically

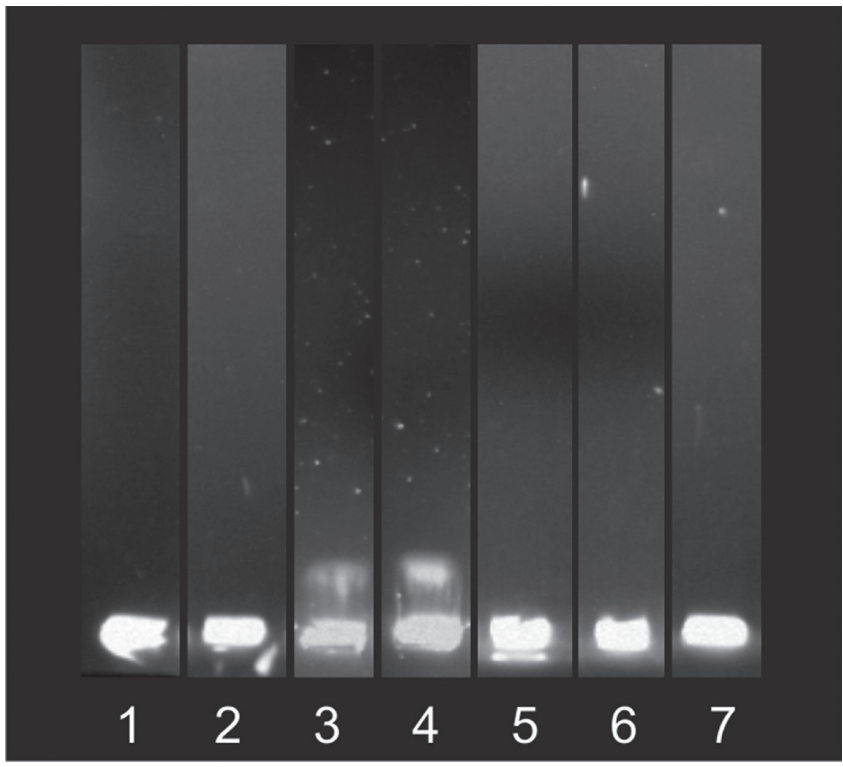

Fig. 2 Results obtained from the CFGE method detecting double strand breaks (DSBs) in freshly isolated human lymphocytes without any treatment (control cells - line 1) or after treatment with hydrogen peroxide $(300 \mu \mathrm{M}$, $5 \mathrm{~min}$, on ice - line 2), the priming dose of zeocin $(50 \mu \mathrm{g} / \mathrm{ml}, 1 \mathrm{~min}$, on ice, in the dark - line 3$)$, the test dose of zeocin $(300 \mu \mathrm{g} / \mathrm{ml}, 1 \mathrm{~min}$, on ice, in the dark - line 4) and plant extracts: G. ascelpiadea methanolic and aqueous haulm extracts (both $0.25 \mathrm{mg} / \mathrm{ml}, 30 \mathrm{~min}$, at $37^{\circ} \mathrm{C}$ - lines 5 and 6) and A. rusticana methanolic root extract $\left(0.025 \mathrm{mg} / \mathrm{ml}, 30 \mathrm{~min}\right.$, at $37^{\circ} \mathrm{C}-$ line 7$)$.

significant difference between further concentrations $(\mathrm{P}>$ 0.05). These findings are in accordance with other results [29] that low doses of bleomycin $(1-5 \mu \mathrm{g} / \mathrm{ml})$ and short treatments (5-15 $\mathrm{min}$ ) produced marked DNA cleavage in mammalian

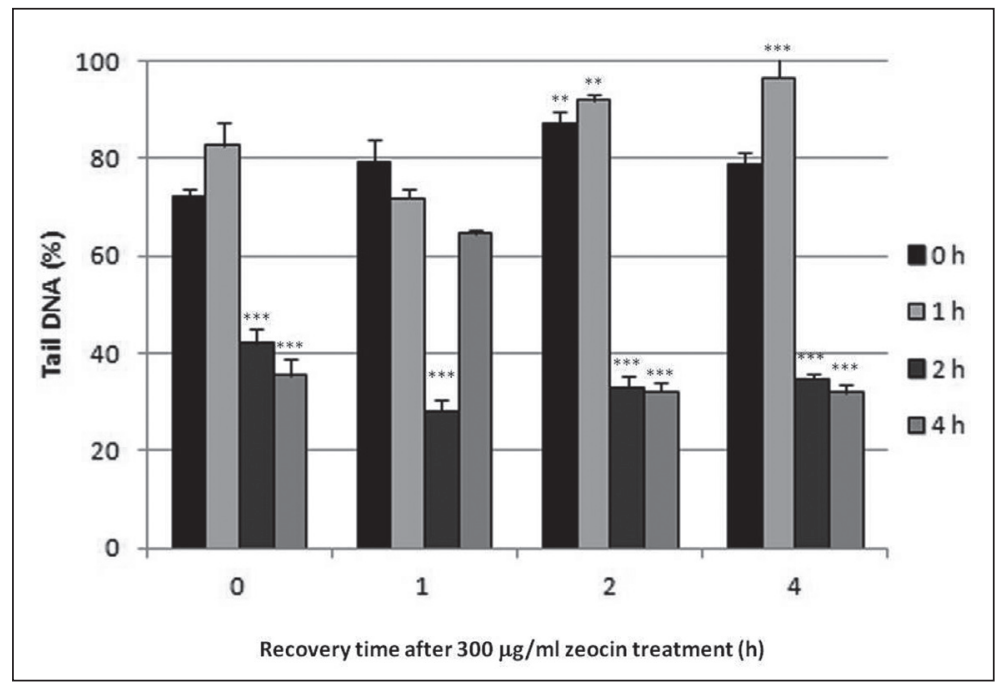

Fig. 3 Adaptive response induced by zeocin in human lymphocytes treated with the priming dose $(50 \mu \mathrm{g} / \mathrm{ml} ; 1 \mathrm{~min})$ and left to recover in $4^{\circ} \mathrm{C}$ for 0,1 , 2 and 4 hours before being treated with the test dose $(300 \mu \mathrm{g} / \mathrm{ml} ; 1 \mathrm{~min})$ and left to recover in $4^{\circ} \mathrm{C}$ for $0,1,2$ and 4 hours in PBS. All experiments were performed for three times. Mean values $\pm \mathrm{SD} .{ }^{\star} P<0.05,{ }^{\star *} P<0.01,{ }^{\star * \star} P<0.001$ 


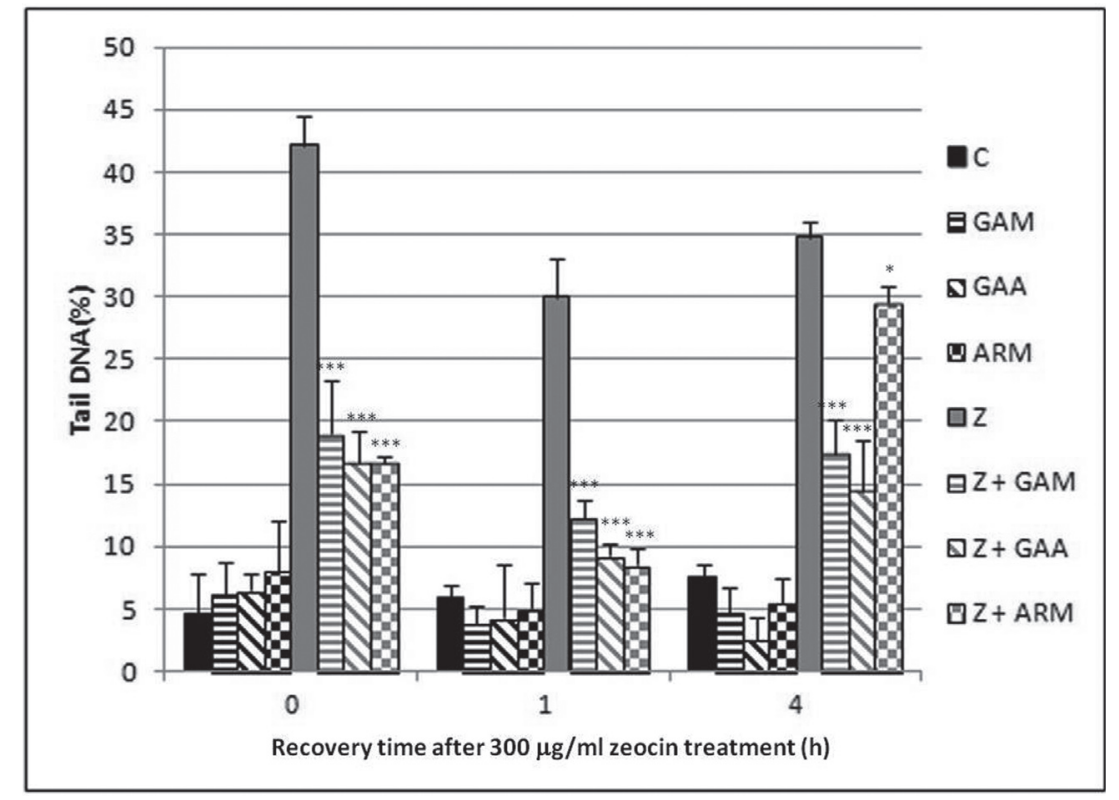

Fig. 4 Comparison of the adaptive response induced in human lymphocytes by zeocin (priming dose $50 \mu \mathrm{g} / \mathrm{ml}$; test dose $300 \mu \mathrm{g} / \mathrm{ml}$, treatment time -1 min; intertreatment time 2 hours; recovery time 0,1 and 4 hours in $\mathrm{PBS}, 4^{\circ} \mathrm{C}$ ) and modulated by Gentiana asclepiadea methanolic and aqueous and Armoracia rusticana methanolic extracts (treatment $30 \mathrm{~min}, 37^{\circ} \mathrm{C}$ ) using the comet assay. C - control cells; $\mathrm{GAM}$ - $\mathrm{G}$. asclepiadea methanolic extract; GAA - G. asclepiadea aqueous extract; ARM - A. rusticana methanolic extract; Z - zeocin; Z + GAM - zeocin and G. asclepiadea methanolic extract; $\mathrm{Z}+$ GAA - zeocin and G. asclepiadea aqueous extract; $\mathrm{Z}+\mathrm{ARM}$ - zeocin and A. rusticana methanolic extract. All experiments were performed three times. Mean values \pm SD. ${ }^{\star} P<0.05,{ }^{*} P<0.01,{ }^{\star * *} P<0.001$

cells, whereas high doses and longer treatment times lead to a relatively small increases in DNA damage above these levels. The comet assay can detect very low level of damage from about 100 up to 3000 breaks per cell and thus these results reflect to the assay limitation where with increased dose the plateu is reached.

Additionally to single strand breaks and AP sites, we found that zeocin exposure can result in DSB (Fig. 2). Our results are in concordance with Chankova et al [4] which found that zeocin causes DSBs in the unicellular green alga Chlamydomonas reinhardtii. Mammalian cells have evolved a number of repair pathways to deal with the various types of DNA damage to maintain genomic integrity. The DSBs are generally regarded as the most toxic of all DNA lesions and can be induced by a variety of DNA-damaging agents, including ionizing radiations and radiomimetic drugs such as bleomycin. DSBs trigger the activation of specific checkpoint signalling pathways that transduce the appropriate biological responses, including cell cycle arrest, DNA repair and apoptosis [30].

Further we wanted to determine whether zeocin could induce the adaptive response in freshly isolated human lymphocytes so we had to optimize and modify experimental conditions. We compared intertreatment and recovery in RPMI or PBS at 37 or $4^{\circ} \mathrm{C}$. Experiments at $37^{\circ} \mathrm{C}$ (data not shown) showed as not suitable due to gel melting as well as due to potential viability problems in long term experiments. As RPMI medium components may interfere with gels, the best combination appeared to be PBS and $4^{\circ} \mathrm{C}$ (Fig. 3). From a wide scale of intertreatment and recovery time, for further experiments we have chosen $2 \mathrm{~h}$-intertreatment time after the priming dose of zeocin and 0,1 and 4 h-recovery time after the test dose of zeocin application.

The adaptive response involves the transcription of many genes and the activation of numerous signalling pathways that trigger cell defenses: more efficient detoxification of free radicals, DNA repair systems, induction of new proteins in irradiated/treated cells with conditioning dose, and enhanced antioxidant production [5]. One of the molecular mechanisms of adaptive response induced by zeocin in lymphocytes was SSBs and predominantly DSBs rejoining [4], similarly as proved before by Chankova et al in C. reinhardtii [4]. In addition, plant extracts significantly accelerated this DNA repair. Moreover, in a previous study we also found that plant extracts protect DNA against oxidation damage and thus we suggest that activation of antioxidant mechanisms could be another way to be included in the adaptive response modulation by both plant extracts.

It was revealed that G. asclepiadea reduced or almost eliminated DNA damage caused by hydrogen peroxide or oxidation DNA lesions caused by silver nanoparticles (unpublished data). In this study we tried to find if these plant extracts can enhance the adaptive response of low dose of zeocin in human lymphocytes. The plant extracts in concentrations $0.25 \mathrm{mg} / \mathrm{ml}$ for G. asclepiadea extracts and $0.025 \mathrm{mg} / \mathrm{ml}$ for A. rusticana extract do not induce DNA damage as confirmed here using the CFGE method for DSBs detection (Fig. 2). They also did 
not exert cytotoxic or genotoxic effect but stimulated proliferation of cells and colony forming ability [31]. Our results show that the haulm extracts from G. asclepiadea could enhance the adaptive response induced with zeocin (Fig. 4) and thus prove biopositive effects of this plant. The most pronounced results were obtained after 1-hour-recovery time after the treatment with the test dose of zeocin. Strand breaks were reduced to $12.25 \%$ after incubation with GAM and even to 9.25\% after GAA treatment. This positive antigenotoxic effect could be explained by the high content of a wide range of biologically active compounds. It is known that zeocin causes oxidative stress and thus we can conclude, that compounds with antioxidant activity such as secoiridoids (swertiamarin) [32] and xanthones (gentisin) which in recent years were reported to have significant pharmacological activities (also antioxidant) based on their diverse structures can be of the great importance in prevention of DNA lesions after zeocin treatment. The antioxidant activities are related to the number of different mechanisms, such as metal ion chelatation [20,33], free-radical scavenging [34], enzyme inhibition [35], and induction of the protective enzymes expression [36]. It was showed that extract from $G$. asclepiadea possesses significant radical scavenging activity, with $\mathrm{IC}_{50}$ (inhibition of $50 \%$ of hydroxyl radical-mediated deoxyribose degradation) value of $53 \mu \mathrm{g} / \mathrm{ml}$. This might be explained by its ability to chelate ferrous ions, thus preventing generation of hydroxyl radicals by Fenton reaction [37]. Moreover, Lim et al. [38] found that isoorientin (present in roots) alone could induce Nrf2 pathway-driven antioxidant response leading to increased expression of antioxidant enzymes such as $\mathrm{NAD}(\mathrm{P}) \mathrm{H}$ quinone oxidoreductase 1 (NQO1). It is likely that the antioxidant potential of the extracts is driven by the bioactive compounds working through both direct and indirect mechanisms. We have also observed slight differences between effect exhibited by methanolic and aqueous extracts. It is possible that different bioactive constituents and/or various amounts of the same component(s) are extracted in methanolic and aqueous extracts and thus may exhibit different effects.

A. rusticana has showed antioxidant, superoxide scavenging potency and also antimutagenic activity [39]. In our experiments we have detected significant decrease in DNA damage after $1 \mathrm{~h}$ of recovery compared to zeocin and only slight decrease in DNA damage after $4 \mathrm{~h}$-recovery time compared to only test dose of zeocin application without extract (Fig. 4). A. rusticana extract appeared to be less effective than G. asclepiadea. A problematic aspect in understanding potential toxicological events relevant to the use of herbs and plant extracts is that the exact amounts of active chemical constituents are frequently unknown. These multiple constituents may work synergistically and could hardly be separated into active parts [40]. Since the extracts have been commonly used as a complex mixture of bioactive components in folk medicine, our goal was to examine the final effect of all the interactions between the components of our extracts. We hypothesise that that some of the compounds may act antagonistically and thus suppress one another actions. For example L-ascorbic acid, which is present in A. rusticana, is known to be a very efficient antioxidant but its degradation depends on varying conditions such as temperature, $\mathrm{pH}$ or processing conditions. On the other hand, another A. rusticana compound, allyl isothiocyanate [41] can be in certain conditions mutagenic and genotoxic [42]. This could be the possible explanation of higher DNA damage detection (Fig. 4) - one of the positively acting compound could be degraded while the other compound acts in these conditions as a genotoxic agent.

To conclude, our study shows a great potential of plant extracts isolated from G. asclepiadea and A. rusticana to modulate adaptive response induced by zeocin in freshly isolated human lymphocytes. We have also modified experimental conditions under which the adaptive response in this test system could be detected. Results obtained in this and our previous studies $[12,30,43]$ confirm important role of plants and plant extracts in prevention against various negative impacts and thus can be potentially used in pharmacology and medicine.

Acknowledgements: We acknowledge the support of internal NILU Grant Health Effects, EEA Research Fund, Contract: PNRF122- AI-1/07 and support of VEGA: 1/0025/11; 2/0072/09; APVT20-00-2604; SK-BG 0017-08.

\section{References}

[1] DIMOVA EG, BRYANT PE, CHANKOVA SG "Adaptive response" - Some underlying mechanisms and open question. Gen Mol Biol, 2008; 31: 396-408.

[2] ACHARY VMM, PANDA BB Aluminium-induced DNA damage and adaptive response to genotoxic stress in plant cells are mediated through reactive oxygen intermediates. Mutagenesis 2010; 25: 201-209. http://dx.doi.org/10.1093/ mutage/gep063

[3] CABISCOL E, TAMARIT J, ROS J Oxidative stress in bacteria and protein damage by reactive oxygen species. Internatl Microbiol 2000; 3: 3-8.

[4] CHANKOVA SG, DIMOVA E, DIMITROVA M, BRYANT PE Induction of DNA double-strand breaks by zeocin in Chlamydomonas reinhardtii and the role of increased DNA double-strand breaks rejoining in the formation of an adaptive response. Radiat Environ Bioph 2007; 46: 409-416. http:// dx.doi.org/10.1007/s00411-007-0123-2

[5] DIMOVA E, BRYANT PE, CHANKOVA SG „Adaptive response“ - Some underlying mechanisms and open questions. Genet Mol Bio 2008; 31: 396-408. http://dx.doi.org/10.1590/ $\underline{\text { S1415-47572008000300002 }}$

[6] HORVATHOVA E, TURCANIOVA V, SLAMENOVA D Comparative study of DNA-damaging and protective effects of selected components of essential plant oils in human leukemic cells K562. Neoplasma 2007; 54: 478-483.

[7] HORVATHOVA E, SLAMENOVA D, MARSALKOVA L, SRAMKOVA M, WSOLOVA L Effects of borneol on the level of DNA damage induced in primary rat hepatocytes 
and testicular cells by hydrogen peroxide. Food Chem Toxicol 2009; 47(6): 1318-1323. http://dx.doi.org/10.1016/ j.fct.2009.03.002

[8] MIADOKOVA E, NADOVA S, VLCKOVA V, DUHOVA V, KOPASKOVA $M$ et al. Antigenotoxic effect of extract from Cynara cardunculus L. Phytother Res 2008; 22: 77-81. http:// dx.doi.org/10.1002/ptr.2268

[9] SLAMENOVA D, SRAMKOVA M, CHALUPA I, SMIGOVA J, KOGAN G Reduction of the genotoxic effects on N-nitrosomorpholine in human hepatoma cells and hamster lung cells by carboxymethyl chitin glucan. Neoplasma 2008; 55: 280-285.

[10] SLAMENOVA D, HORVATHOVA E, CHALUPA I, WSOLOVA L, NAVAROVA J Ex vivo assessment of protective effects of carvacrol against DNA lesions induced in primary rat cells by visible light excited methylene blue (VL+MB). Neoplasma 2011; 58: 14-19. http://dx.doi.org/10.4149/neo 2011_01_14

[11] SGHAIER BM, BHOURI W, MEFFATI A, BOUBAKER J, SKANDRANI I et al. Chemical investigation of different crude extracts from Teucrium ramosissimum leaves. Correlation with their antigenotoxic and antioxidant properties. Food Chem Toxicol. 2011;49(1):191-201. http://dx.doi.org/10.1016/ j.fct.2010.10.016

[12] HASPLOVA K, HUDECOVA A, MIADOKOVA E, MAGDOLENOVA Z, GALOVA E et al. Biological activity of plant extract isolated from Papaver rhoeas on human lymfoblastoid cell line. Neoplasma 2011; 58: 386-391. http://dx.doi. org/10.4149/neo $201105 \quad 386$

[13] MATSUKAWA K, OGATA M, HIKAGE T, MINAMI H, SHIMOTAI Y et al. Antiproliferative activity of root extract from Gentian plant (Gentiana triflora) on cultured and implanted tumor cells. Biosci Biotech Biochem 2006; 70: 1046-1048. http://dx.doi.org/10.1271/bbb.70.1046

[14] GEORGIEVA E, HANDJIEVA N, POPOV S, EVSTATIEVA L Comparative analysis of the volatiles from flowers and leaves of three Gentiana species. Biochem Sys Ecol 2005; 33: 938-947. http://dx.doi.org/10.1016/j.bse.2005.01.002

[15] JIANG RW, WONG KL, CHAN YM, XU HX, BUT PPH et al. Isolation of iridoid and secoiridoid glycosides and comparative study on Radix gentianae and related adulterants by HPLC analysis. Phytochemistry 2005; 66: 2674-2680. http://dx.doi. org/10.1016/j.phytochem.2005.09.028

[16] Jensen SR, SHRIPSEMA J Chemotaxonomy and pharmacology of Gentianaceae. In: Struwe L, Albert VA, editors. Gentianaceae - Systematics and Natural History. New York: Cambridge University Press: Cambridge, 2002: 573-631.

[17] OZTURK N, KORKMAZ Y, OZTURK Y, HUSNU CAN BASER K Effects of gentiopicroside, sweroside and swertiamarine, secoiridoids from gentian (Gentiana lutea ssp. Symphyandra), on cultured chicken embryonic fibroblasts. Planta Med 2006; 72: 289-294. http://dx.doi.org/10.1055/s2005-916198

[18] WU QX, LIU X, SHI YP Chemical components from Gentiana aristata. Chem Biodivers 2007; 4: 175-182.

[19] WU M, WU P, LIU M, XIE H, JIANG Y et al. Iridoids from Gentiana loureirii. Phytochemistry 2009; 70: 746-750. http:// dx.doi.org/10.1016/j.phytochem.2009.03.018
[20] MIHAILOVIC V, VUKOVIC N, NICIFOROVIC N, SOLUJIC $\mathrm{S}, \mathrm{MLADENOVIC} \mathrm{M}$ et al. Studies on the antimicrobial activity and chemical composition of the essential oils and alcoholic extracts of Gentiana asclepiadea L. J Med Plants Res 2011; 5: 1164-1174.

[21] DINDA B, DEBNATH S, HARIGAYA Y Naturally occuring secoiridoids and bioactivity of naturally occuring iridoids and secoiridoids. A review, part 2. Chem Pharm Bull 2007; 55: 689-728. http://dx.doi.org/10.1248/cpb.55.689

[22] TUNDIS R, LOIZZO MR, MENICHINI F, STATTI GA, MENICHINI F Biological and pharmacological activities of iridoids: recent developments. Mini-Rev Med Chem 2008; 8: 399-420. http://dx.doi.org/10.2174/138955708783955926

[23] VEITCH NC Horseradish peroxidase: a modern view of a classic enzyme. Phytochemistry 2004; 65: 249-259. http://dx.doi. org/10.1016/j.phytochem.2003.10.022

[24] Li X, KUSHAD MM Purification and characterization of myrosinase from horseradish (Armoracia rusticana) roots. Plant Physiol Biochem 2005;43: 503-511. http://dx.doi. org/10.1016/j.plaphy.2005.03.015

[25] WEIL MJ,ZHANG Y, NAIR MG Tumor cell proliferation and cyclooxygenase inhibitory constituents in horseradish (Armoracia rusticana) and Wasabi (Wasabia japonica). J Agric Food Chem 2005; 53 :1440-1444. http://dx.doi.org/10.1021/jf048264i

[26] COLLINS AR, DUSINSKA M, GEDIK CM, STETINA R Oxidative damage to DNA: Do we have a reliable biomarker? Environ Health Perspect 1996; 104: 465-469.

[27] CHANKOVA SG, BRYANT PE Acceleration of DNAdouble strand rejoining during the adaptive response of Chlamydomonas reinhardtii. Radiats. Biol. Radioecol. 2002; 42: 600-603.

[28] MASON RW, BERGMAN CA, LU G, HOLBROOK JF, SOLCHURCH K Expression and characterization of cathepsin P. Biochem J 2004; 378: 657-663

[29] Lopez-Larraza D, DE LUCA JC, BIANCHI NO The kinetics of DNA damdge by blemycin in mammalian cells. Mutat Res 1990; 232: 57-61. http://dx.doi.org/10.1016/00275107(90)90110-P

[30] TRASTOY MA, DEFAIS M, LARMINAT F Resistance to the antibiotic Zeocin by stable expression of the Sh ble gene does not fully suppress Zeocin-induced DNA cleavage in human cells. Mutagenesis. 2005; 20: 111-114. http://dx.doi. org/10.1093/mutage/gei016

[31] HUDECOVA A, HASPLOVA K, MIADOKOVA E, MAGDOLENOVA Z, RINNA A et al. Cytotoxic and genotoxic effect of methanolic flower extract from Gentiana asclepiadea on COS 1 cells. Neuroendocrinol let 2010; 31(2): 101-105.

[32] JAISHREE V, BADAMI S Antioxidant and hepatoprotective effect of swertiamarin from Enicostemma axillare against $\mathrm{D}$-galactosamine induced acute liver damage in rats. J Ethnoparmacol 2010; 130: 103-106. http://dx.doi.org/10.1016/ j.jep.2010.04.019

[33] MILLER E, MALINOWSKA K, GALECKA E, MROWICKA M, KEDZIORA J Role of flavonoids as antioxidants in human organism. Pol Merkur Lekarski 2008; 24: 556-560.

[34] KUMAR S, MALHORTA R, KUMAR D Antidiabetic and Free Radicals Scavenging Potential of Euphorbia hirta Flower 
Extract. Indian J Pharm Sci. 2010;72(4): 533-7. http://dx.doi. org/10.4103/0250-474X.73921

[35] MAHESHWARI A, MISRO MM, AQQARWAL A, SHARMA RK, NANDAN N-Acetyl-L-cysteine counteracts oxidative stress and prevents $\mathrm{H} 2 \mathrm{O} 2$ induced germ cell apoptosis through down-regulation of caspase-9 and JNK/c-Jun. Mol Reprod Dev. 2010 1-11.

[36] MYHRSTAD MC, CARLSEN H, NORDSTROM O, BLOMHOFF R, MOSKAUG JO Flavonoids increase the intracellular glutathione level by transactivation of the gamma-glutamylcysteine synthetase catalytical subunit promoter. Free Radic Biol Med 2002; 32: 386-393. http://dx.doi.org/10.1016/S0891$\underline{5849(01) 00812-7}$

[37] NICIFOROVIC N, MIHAILOVIC V, MASKOVIC P, SOLUJIC S, STOJKOVIC A et al. Antioxidant activity of selected plant species; potential new sources of natural antioxidants. Food Chem Toxicol 2010; 3125-3130. http://dx.doi.org/10.1016/ j.fct.2010.08.007

[38] LIM JH, PARK HS, CHOI JK, LEE IS, CHOI HJ Isoorientin induces Nrf2 pathway-driven antioxidant response through phosphatidylinositol 3-kinase signaling. Arch Pharm Res 2007; 30: 1590-1598. http://dx.doi.org/10.1007/BF02977329
[39] KINAE N, MASUdA H, SHIN ILS, FURUGORI M, SHIMOI K Functional properties of wasabi and horseradish. Biofactors 2000; 13:265-269. http://dx.doi. org/10.1002/biof.5520130140

[40] SILVA CR, MONTEIRO MR., ROCHA HM., RIBEIRO AF, CALDEIRA-DE-ARAUJO A et al. Assessment of antimutagenic and genotoxic potential of senna (Cassia angustifolia Vahl.) aqueous extract using in vitro assays. Toxicol in Vitro 2008; 22: 212-218. http://dx.doi.org/10.1016/ j.tiv.2007.07.008

[41] CHEN H, AKINKUROLERE RO, ZHANG H Fumigant activity of plant essential oil from Armoracia rusticana (L.) on Plodia interpunctella (Lepidoptera: Pyralidae) and Sitophilus zeamais (Coleoptera: Curculionidae). Afr J Biotechnol 2011; 10: 1200-1205

[42] KASSIE F, KNASMULLER S Genotoxic effects of allyl isothiocyanate (AITC) and phenethyl isothiocyanate (PEITC). Chem-Biol Interact 2000; 127: 163-180. http://dx.doi. org/10.1016/S0009-2797(00)00178-2

[43] NADOVA S, MIADOKOVA E, CIPAK L Flavonoids potentiate the efficacy of cytarabine through modulation of drug-induced apoptosis. Neoplasma 2007; 54: 202-206. 